\title{
Front Matter: Volume 10063
}

, "Front Matter: Volume 10063," Proc. SPIE 10063, Dynamics and Fluctuations in Biomedical Photonics XIV, 1006301 (28 April 2017); doi: 10.1117/12.2275996

SPIE. Event: SPIE BiOS, 2017, San Francisco, California, United States 


\title{
Dynamics and Fluctuations in Biomedical Photonics XIV
}

\author{
Valery V. Tuchin \\ Kirill V. Larin \\ Martin J. Leahy \\ Ruikang K. Wang \\ Editors
}

29-30 January 2017

San Francisco, California, United States

Sponsored and Published by

SPIE 
The papers in this volume were part of the technical conference cited on the cover and title page. Papers were selected and subject to review by the editors and conference program committee. Some conference presentations may not be available for publication. Additional papers and presentation recordings may be available online in the SPIE Digital Library at SPIEDigitallibrary.org.

The papers reflect the work and thoughts of the authors and are published herein as submitted. The publisher is not responsible for the validity of the information or for any outcomes resulting from reliance thereon.

Please use the following format to cite material from these proceedings:

Author(s), "Title of Paper," in Dynamics and Fluctuations in Biomedical Photonics XIV, edited by Valery V. Tuchin, Kirill V. Larin, Martin J. Leahy, Ruikang K. Wang, Proceedings of SPIE Vol. 10063 (SPIE, Bellingham, WA, 2017) Seven-digit Article CID Number.

ISSN: 1605-7422

ISSN: 2410-9045 (electronic)

ISBN: 9781510605671

ISBN: 9781510605688 (electronic)

Published by

SPIE

P.O. Box 10, Bellingham, Washington 98227-0010 USA

Telephone +1 3606763290 (Pacific Time) · Fax +1 3606471445

SPIE.org

Copyright @ 2017 , Society of Photo-Optical Instrumentation Engineers.

Copying of material in this book for internal or personal use, or for the internal or personal use of specific clients, beyond the fair use provisions granted by the U.S. Copyright Law is authorized by SPIE subject to payment of copying fees. The Transactional Reporting Service base fee for this volume is $\$ 18.00$ per article (or portion thereof), which should be paid directly to the Copyright Clearance Center (CCC), 222 Rosewood Drive, Danvers, MA 01923. Payment may also be made electronically through CCC Online at copyright.com. Other copying for republication, resale, advertising or promotion, or any form of systematic or multiple reproduction of any material in this book is prohibited except with permission in writing from the publisher. The CCC fee code is $1605-7422 / 17 / \$ 18.00$.

Printed in the United States of America.

Publication of record for individual papers is online in the SPIE Digital Library.

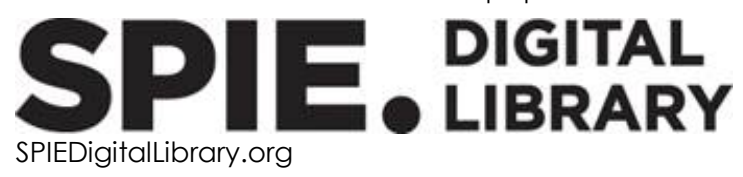

Paper Numbering: Proceedings of SPIE follow an e-First publication model. A unique citation identifier (CID) number is assigned to each article at the time of publication. Utilization of CIDs allows articles to be fully citable as soon as they are published online, and connects the same identifier to all online and print versions of the publication. SPIE uses a seven-digit CID article numbering system structured as follows:

- The first five digits correspond to the SPIE volume number.

- The last two digits indicate publication order within the volume using a Base 36 numbering system employing both numerals and letters. These two-number sets start with 00, 01, 02, 03, 04, 05, $06,07,08,09,0 A, O B \ldots$. OZ, followed by 10-1Z, 20-2Z, etc. The CID Number appears on each page of the manuscript. 


\title{
Contents
}

\author{
vii Authors \\ ix Conference Committee \\ xi Introduction
}

\section{SPECKLE TECHNOLOGIES}

1006303 Laser Doppler flowmetry in blood and lymph monitoring, technical aspects and analysis [10063-3]

1006305 Unobtrusive monitoring of heart rate using a cost-effective speckle-based SI-POF remote sensor [10063-5]

1006306 Optical vortices as potential indicators of biophysical dynamics [10063-6]

\section{TISSUE AND CELL DYNAMICS}

$10063 \mathrm{OH}$ Characterizing microstructural features of biomedical samples by statistical analysis of Mueller matrix images [10063-17]

\section{FUNCTIONAL IMAGING}

10063 OM Prototype of an opto-capacitive probe for non-invasive sensing cerebrospinal fluid circulation (Invited Paper) [10063-22]

10063 ON Intrinsic fluorescence of protein in turbid media using empirical relation based on Monte Carlo lookup table [10063-23]

$100630 Q \quad$ Noise sources in Raman spectroscopy of biological objects [10063-26]

10063 OR Diagnostics of oral lichen planus based on analysis of volatile organic compounds in saliva [10063-27]

\section{OCT PLUS SPECKLE IMAGING II}

10063 OT Spectral contrast-enhanced optical coherence tomography for improved detection of tumor microvasculature and functional imaging of lymphatic drainage [10063-29] 
10063 OV Optical diagnosis of cervical cancer by intrinsic mode functions [10063-9]

10063 OW Optical diagnosis of cervical cancer by higher order spectra and boosting [10063-16]

10063 OY Influence of cost functions and optimization methods on solving the inverse problem in spatially resolved diffuse reflectance spectroscopy [10063-32]

1006310 Recurrence quantification as potential bio-markers for diagnosis of pre-cancer [10063-34]

1006311 Continuous blood pressure recordings simultaneously with functional brain imaging: studies of the glymphatic system [10063-35]

1006314 Intermittent behavior in the brain neuronal network in the perception of ambiguous images [10063-38]

1006315 Polarization enhanced laser speckle contrast imaging for vascular dynamic study [10063-39]

1006316 Intermittent phase synchronization in human epileptic brain [10063-40]

1006317 Recognition and classification of oscillatory patterns of electric brain activity using artificial neural network approach [10063-41]

1006318 Filtration of human EEG recordings from physiological artifacts with empirical mode method [10063-42]

1006319 The study of cognitive processes in the brain EEG during the perception of bistable images using wavelet skeleton [10063-43]

$100631 \mathrm{~A}$ Temperature sensing of adipose tissue heating with the luminescent upconversion nanoparticles as nanothermometer: in vitro study [10063-44]

10063 1C Pattern formation in adaptive multiplex network in application to analysis of the complex structure of neuronal network of the brain [10063-46]

10063 ID Influence of earlobe thickness on near infrared spectroscopy [10063-47]

$100631 \mathrm{E}$ Experimental study on the influence of the contact pressure to transmittance and reflectance spectra by near infrared spectroscopy [10063-48]

10063 IF Artifact removal from EEG data with empirical mode decomposition [10063-49]

$100631 \mathrm{G}$ Common-path biodynamic imaging for dynamic fluctuation spectroscopy of 3D living tissue [10063-50]

$100631 \mathrm{H} \quad$ Numerical and analytical investigation of the chimera state excitation conditions in the Kuramoto-Sakaguchi oscillator network [10063-51] 
1006311 The control of the frequency of the sub-terahertz source on the semiconductor superlattices for biophysical applications with use the change of the doping density [10063-52]

$100631 \mathrm{~J}$ Numerical analysis of the chimera states in the multilayered network model [10063-53]

$10063 \mathrm{lL}$ Comparative study of the optical properties of colon mucosa and colon precancerous polyps between 400 and $1000 \mathrm{~nm}$ [10063-56] 
Proc. of SPIE Vol. $100631006301-6$

Downloaded From: https://www.spiedigitallibrary.org/conference-proceedings-of-spie on 26 Apr 2023 Terms of Use: https://www.spiedigitallibrary.org/terms-of-use 


\section{Authors}

Numbers in the index correspond to the last two digits of the seven-digit citation identifier (CID) article numbering system used in Proceedings of SPIE. The first five digits reflect the volume number. Base 36 numbering is employed for the last two digits and indicates the order of articles within the volume. Numbers start with 00, 01, 02, 03, 04, 05, 06, 07, 08, 09, OA, OB...0Z, followed by 10-12, 20-2Z, etc.

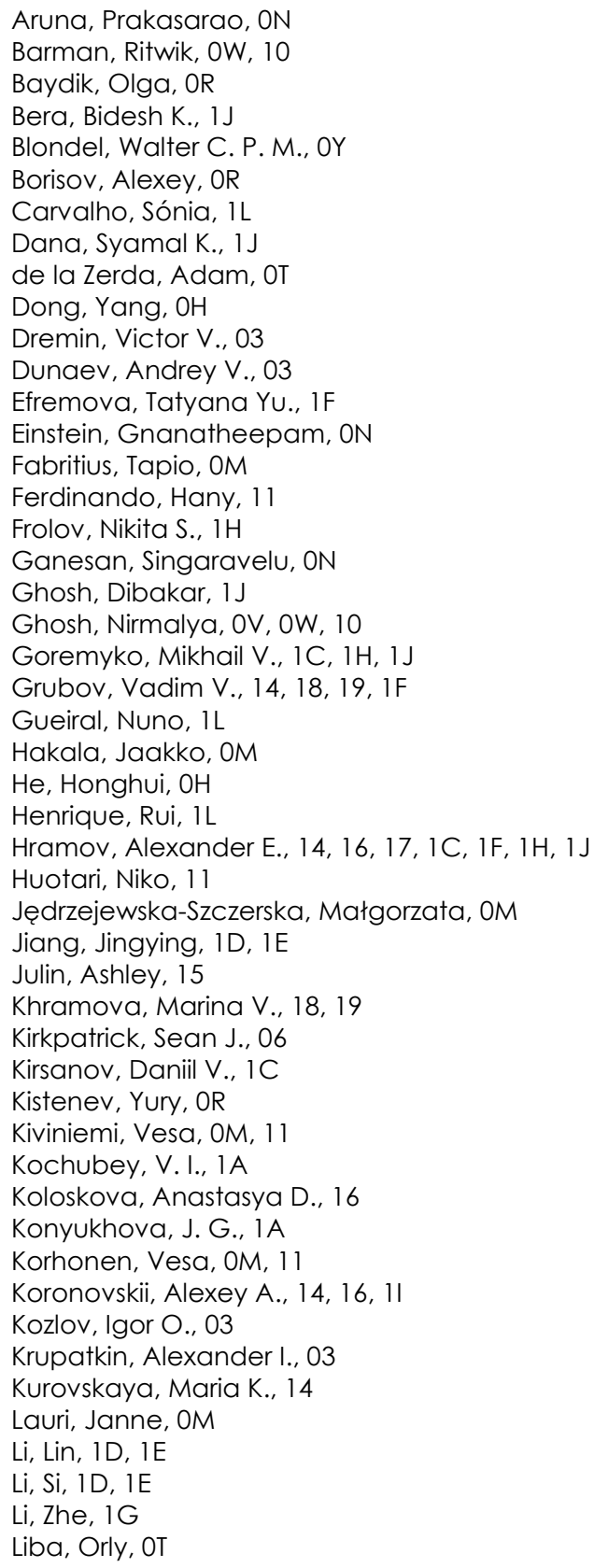

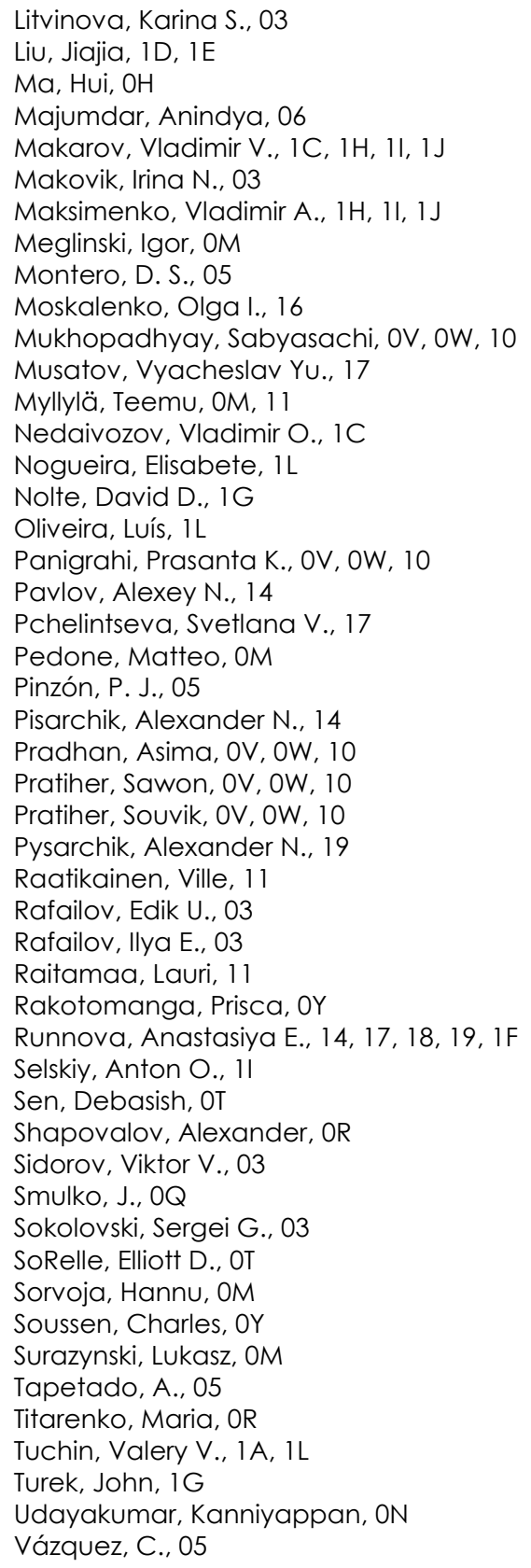


Vihriälä, Erkki, OM, 11

Volkova, E. K., 1A

Wang, Tianpei, ID, 1E

Wróbel, Maciej, S., OM, OQ

Xia, Jinjun, 15

XU, Kexin, 1D, 1E

Yanina, I. YU., IA

Zaharevich, A. M., 1A

Zherebtsov, Evgeny A., 03

Zhou, Jialing, $\mathrm{OH}$

Zhuravlev, Maksim O., 14, 16, 19

Zienkiewicz, Aleksandra, 0M, 11 


\title{
Conference Committee
}

\author{
Symposium Chairs
}

James G. Fujimoto, Massachusetts Institute of Technology

(United States)

R. Rox Anderson, Wellman Center for Photomedicine, Massachusetts General Hospital (United States)and Harvard School of Medicine (United States)

Program Track Chair

Steven L. Jacques, Oregon Health \& Science University (United States)

\section{Conference Chairs}

Valery V. Tuchin, N.G. Chernyshevsky Saratov National Research State University (Russian Federation), National Research Tomsk State University (Russian Federation), and Institute of Precision Mechanics and Control (Russian Federation)

Kirill V. Larin, University of Houston (United States)

Martin J. Leahy, National University of Ireland, Galway (Ireland)

Ruikang K. Wang, University of Washington (United States)

Conference Program Committee

Pierre O. Bagnaninchi, The University of Edinburgh (United Kingdom)

Wei R. Chen, University of Central Oklahoma (United States)

Joseph P. Culver, Washington University School of Medicine in St. Louis (United States)

Ekaterina I. Galanzha, University of Arkansas for Medical Sciences United States)

Miya Ishihara, National Defense Medical College (Japan)

Jingying Jiang, Tianjin University (China)

Vesa Kiviniemi, University of Oulu (Finland)

Jürgen M. Lademann, Charité Universitätsmedizin Berlin (Germany)

Hong Liu, The University of Oklahoma (United States)

Qingming Luo, Huazhong University of Science and Technology (China)

Igor V. Meglinski, University of Oulu (Finland)

Brian S. Sorg, National Cancer Institute (United States)

Vladislav Toronov, Ryerson University (Canada)

Lihong V. Wang, Washington University in St. Louis (United States)

Ying Yang, Keele University (United Kingdom) 
Anna N. Yaroslavsky, University of Massachusetts Lowell

(United States)

Vladimir P. Zharov, University of Arkansas for Medical Sciences

(United States)

Dan Zhu, Huazhong University of Science and Technology (China)

\section{Session Chairs}

1 Speckle Technologies

Anna N. Yaroslavsky, University of Massachusetts Lowell (United States)

2 Clinical Imaging

Joseph P. Culver, Washington University School of Medicine in St. Louis (United States)

3 Keynote Session

Valery V. Tuchin, N.G. Chernyshevsky Saratov National Research State University (Russian Federation), National Research Tomsk State University (Russian Federation), and Institute of Precision Mechanics and Control (Russian Federation)

4 OCT Plus Speckle Imaging I

Qingming Luo, Huazhong University of Science and Technology (China)

5 Tissue and Cell Dynamics

Igor Meglinski, University of Oulu (Finland)

Dan Zhu, Huazhong University of Science and Technology (China)

6 Optical Clearing and Biomechanics: Joint Session with

Conferences 10063 and 10067

Kirill V. Larin, University of Houston (United States)

Martin J. Leahy, National University of Ireland, Galway (Ireland)

David D. Sampson, The University of Western Australia (Australia)

Valery V. Tuchin, N.G. Chernyshevsky Saratov National Research State University (Russian Federation), National Research Tomsk State University (Russian Federation), and Institute of Precision Mechanics and Control (Russian Federation)

7 Functional Imaging

Vladimir P. Zharov, University of Arkansas for Medical Sciences (United States)

Miya Ishihara, National Defense Medical College (Japan)

8 OCT Plus Speckle Imaging II

Kirill V. Larin, University of Houston (United States) 


\section{Introduction}

Dynamics and Fluctuations in Biomedical Photonics XIV was held 29-30 January 2017, at the SPIE Photonics West Conference in San Francisco, California. The goal of the conference was to gather essentially different groups of leading researchers such as biophysicists, medical doctors and physicians, mathematicians, and optical and laser engineers, together with students to report the current state of the art and to facilitate future progress in the development of optical and laser technologies based on dynamics and fluctuations approaches towards biomedical science and clinical applications (such as laser-speckle, specklebased coherence imaging, microcirculation analysis using various optical techniques and methods, dynamics of molecular diffusion, including nanoparticles, etc.). These approaches should be useful for diagnosis and therapy of devastating life-threatening diseases such as those of the heart, cancer, vascular, mental illness, and many others that manifest as a breach of the living organism's immune systems at the level of molecule, cell, organ, or organism as a whole. We hope that proceedings of this conference will contribute to the development of such interdisciplinary fields of science and applications as dynamics and structures of living systems, biomedical optics and laser medicine, and that it will be useful to scientists, medical doctors, engineers and students.

Martin J. Leahy also moderated "Panel Discussion on Biophotonic Methods for detection, monitoring and imaging of Lymph Circulation". The panel discussion was on the lymph transport network and the recently discovered glymph network within the brain. The 2012 discovery of a lymph-like system in the brain has intensified the need to image and measure lymph and the brain's glymph (socalled because of the important role of glial channels) structure and function. Malfunction of lymph is associated with diseases including cancer and in glymph is associated with neurodegenerative disease. Biophotonics is well placed to fill this need and many of our colleagues have already demonstrated techniques for this purpose. These include: Microscopy, Imaging, Photoacoustics, Raman, OCT, MRI, PET, Speckle, Optical Clearing and Optogenetics. The study of (g)lymph pulsations; (g)lymphatic, endothelial, pericytes and smooth muscle cell function, (g)lymphangiogenesis, lymph chemistry; circulating tumor, immune cells and other materials all require more advanced techniques for discovery, diagnosis and therapy. This panel discussion reviewed the state of the art and discussed what has and should be done by our community to provide the necessary tools.

The panel discussion followed several related talks in the Dynamics and Fluctuations Conference, including an excellent keynote lecture by Ekaterina Galanzha on "Nanobiophotonics breaks lymphatic theranostic challenges." Galanzha illustrated the discovery of lymph in the seventeenth century, its neglect for two centuries, and its subsequent rise in the mid-twentieth century. There have been over 12,000 publications in the past half century. She outlined the main 
methods used to image and measure lymph flow as well as an innovative technique for the ablation of circulating tumour cells. Together with Valery Tuchin, N.G. Chernyshevsky Saratov National Research State University (Russian Federation), she illustrated the importance of lymph in more than a dozen common diseases. Tuchin further described optical clearing for better visualization and animal models aimed at better understanding the lymph role in cancer. Gross lymph transport in adults and children was illustrated in videos provided by Eva Sevick, where the lymph was loaded with indocyanine green and its fluorescence detected.

Stanislav Emelianov described the use of ultrasound and photoacoustics along nanodroplets, microbubbles and molecular probes or endogenous contrast ( haemoglobins) as appropriate to for example, elucidate the production of micrometastatic foci are formed in sentinel lymph node within a few weeks of primary fumour formation. The developments in ultrasound and photoacoustics for anatomical, functional and cellular/molecular imaging, represent a powerful array of tools to understand, track and treat cancer.

However, (g)lymph imaging in the brain is among the great challenges for biophotonics imaging. Lihong Wang previously demonstrated the possibility to image blood vessels inside the intact human skull using photoacoustics and together with his imaging of vasculature and lymphatics in the whole mouse, this would appear to be a good candidate for glymphatic imaging in the brain.

Teema Myllylä described the blood brain barrier and relationship to the glymphatic system. He further showed the opening of the BBB through intra-arterial mannitol infusion. Oxana Semyachkina-Glushkovskaya discussed drugs.

Additionally, most of the sessions featured invited presentations. These presentations drew significant attention from the audience and resulted in wide coffee break discussions. The oral sessions and corresponding poster session featured many presentations that described different methods and techniques developed and applied to study complex problems of dynamics and fluctuations in biological systems on the scale ranging from cell to the whole body. The reader is encouraged to browse the table of contents for this issue to learn the full scope of the conference.

\author{
Valery V. Tuchin \\ Kirill V. Larin \\ Martin J. Leahy \\ Ruikang K. Wang
}

